\title{
THE IDENTITY OF SIMIRA TINGTORIA AUBL.
}

\author{
BY \\ C. E. B. BREMEKAMP \\ (Botanical Museum, Utrecht)
}

(Received Dec. 18th, 1953)

Aublet described and figured in his "Histoire des Plantes de la Guiane Francoise" (Vol. I p. 170-172 and Vol. III t. 65, 1775) under the name Simira tinctoria a tree belonging to the family Rubiaceae which until very recently was represented in the herbaria solely by specimens that he himself had collected. One of these specimens is preserved in the herbarium of the British Museum (Natural History) and another one in the "Herbier Denaiffe" (cf. Lanjouw, J. and H. Uitrien in Rec. d. trav. bot. Néerl. 37, 357, 1940), which was recently acquired by the Muséum d'Histoire Naturelle, Paris.

AUbLET's new genera were viewed in his own time and even long afterwards with considerable distrust, and when we see that their separation from older and already well-known allies is but rarely justified by the contents of his diagnoses, this attitude becomes comprehensible. However, when we take the trouble to examine the material on which his new genera were founded, we are often forced to admit that his intuition had shown him the right way. This applies e.g. to the genera that were separated by him from Psychotria L, viz. Ronabea, Tapogomea, Carapichea, Palicourea, Mapouria and Nonatelia. The taxonomists of AUBLET's own time and those of theimmediately following period reduced all these genera to Psychotria, but these authors based their opinion almost exclusively on AUBLET's insufficiently explicit descriptions. In a later period, when the plants on which Aubler had founded his genera, were more thoroughly studied, it was gradually recognized that their reduction to Psychotria was not justified.

The description of Simira is preceded in AuBLET's work by the descriptions of Ronabea, Tapogomoa and Carapichea and followed by those of Palicourea and Mapouria, all of them genera belonging to the Psychotrieae and nearly related to Psychotria itself, and the description of Simira does not contain a single item that would exclude it from this group. It reads as follows:

"GAL. PERIANTHIUM monophyllum, turbinatum, quinquedentatum

COR. monopetala, tubulosa, disco suprà ovarium inserta; limbus quinquefidus, lobis subrotundis 
STAM. FILAMENTAquinque, tubo corollae inserta. ANTHERAE biloculares

PIST. GERMEN ovatum, calice denticulatum, disco coronatum. STYLUS longus, tenuis, apice bipartitus. STIGMATA obtusa

PER. Bacca ovata, calicis dentibus coronata, bilocularis

SEM. solitaria."

Apart from the "lobi subrotundi" of the corolla limb, which suggest, but do not prove, a non-valvate aestivation, there is nothing in this description that does not apply to Psychotria. That the ovules are in reality not solitary but densely packed on a placenta with which they form an oblong mass that can easily be mistaken for a solitary ovule, could, of course, not be guessed, and the authors who reduced AuBLET's preceding and following genera to Psychotria, had therefore every reason to do the same with Simira. The first to treat Simira in this way was RAEuschel, who in his "Nomenclator Botanicus" (ed. 3, pl 55, 1797) published the combination Psychotria tinctoria". The next was WiLldenow, who in his "Species Plantarum" (I, 962, 1798) replaced Aublet's epithet "tinctoria" by "parviflora". RoEMER and Schultes in their "Systema Vegetabilium" (V, 187, 1819) followed suit, but adopting a practice that was not uncommon at that time they used the original generic name "Simira" as specific epithet.

The correctness of the view that the genus Simira should be reduced to Psychotria, has apparently never been questioned, and the fact that the stipules shown in Aublet's plate are of a type that is never met with either in Psychotria or in any of the latter's nearest allies seems to have been completely overlooked. The form of these stipules for a long time puzzled me, but although it made the position of Simira in the Psychotrieae in my opinion extremely doubtful, it gave no distinct indication with regard to its real position. For this reason I heartily wellcomed the opportunity to study one of AUBLET's specimens, that was offered to me last year during my visit to the British Museum of Natural History. For this opportunity I tender my best thanks to Dr G. TAYLOR, the Keeper of Botany.

It is true that the specimen preserved in the herbarium of the British Museum is a rather poor one, for it does not possess a single complete flower, but it sufficed for the determination of the position of the genus. A cursory examination of the vegetative parts confirmed my surmise that the plant could not belong to the Psychotrieae, for raphides proved

1) RaEuschel's new combinations can hardly be regarded as validly published (cf. Art. 42 of the International Code of Botanical Nomenclature), for the binomia on which they are based, are omitted, and even the name of the original author is left out. In the case of Psychotria tinctoria no mention is made of the basic combination Simira tinctoria, and AUBLE's's name is not recorded. The main arguments for considering it a new combination based on AuBlet's binomium are that at the time no other Ps. tinctoria was known and that Guiana is given as the country of origin. Additional evidence is found in the circumstance that the representatives of AUBLET's other new genera which with more or less right were reduced to Psychotria, were treated by him in the same cryptic way. In my opinion, the earlier taxonomists, who ignored RaEuschez's "Nomenclatur" were right. 
to be entirely absent. Positive indications as to its position were obtained by a study of the ovary, of which a sufficient number were present. The dissection of one of the latter revealed that AUBLET, as stated above, had made a mistake when he described the ovules as solitary. The placenta, moreover, proved to be of a type that was known so far from one genus only, viz. from Sickingia Willd. Everyone who has seen the placentae of this genus, will agree that no mistake is possible (cf. e.g. the figures of the placentae of S. Glazovii K. Sch. and of $S$. Oliveri K. Sch. given by Schumann in Martius, Flora Brasiliensis (VI, 6, t. 117 et t. 118, 1889). This similarity in the structure of the placentae would already be sufficient to identify Simira with Sickingia, but in the other characters too there is a very pleasurable agreement. In Simira as well as in Sickingia the leaves are large and provided with numerous lateral nerves, the stipules are interpetiolar and long and pointed, raphides are absent and the bast contains a peculiar red dye. Aublex refers to the latter in the Latin text in the following way: "cortex trunci extùs rufescens, intus rubet" and a little further he adds "cortex utilis ad pannos sericeos et gossipinos rubro colore inficiendos". In the French text he gives more details: "Son écorce est épaisse, roussâtre en dehors et rouge intérieurement" and further "L'écorce de cet arbre trempée dans l'eau lui communique bientôt une couleur d'un beau rouge: on prétend que cette écorce peut être employée dans la teinture. Les essais qu'on. en a fait à Caïenne, donnent lieu de croire qu'elle seroit d'une grande utilité pour teindre en rouge vif la soie et le cotton." A similar substance is known to occur in the bast of several Sickingia species and may be present in all of them.

The genus Sickingia was created by WILLDENOw in "Neue Schriften d. Gesellsch. naturf. Freunde zu Berlin".(III, 445, 1800), and is therefore much younger than Simira. It originally comprised two species, viz. S. erythroxylon Willd. and S. longifolia Willd. SPRENGEL. (Syst. Veg. I, 622, 1825) referred Platycarpum orinocense M.B. to it, but this was a mistake which was afterwards rectified. Better informed was Hooker F., who in BeNTH. et Hook. F., Genera Plantarum II, 34, 1873 added S. cordifolia. Baillon, who wrongly reduced Sickingia to a subgenus of Chimarrhis DG ${ }^{1}$, described three more species and transferred a fourth species to it. Schumann in Mart., Fl. Bras. VI, 6, 225-234, 1889 restored Sickingia to its original rank and raised the number of species to 14 , and in the course of this century the latter was brought, mainly by the efforts of STANDLEY, to 32 .

In view of the comparatively large number of species that have been described in Sickingia, it might seem undesirable to replace this name by Simira. It can certainly not been denied that many generic names have been conserved whose claims carried less conviction, but this can hardly be considered a sufficient excuse for a new infringement of the priority rule. In order to make it quite clear that in my opinion all species that have rightfully been referred to Sickingia should be

1 See my remarks on the systematic position of Sickingia in Verh. Kon. Ned. Akad. v. Wetensch. Afd. Natuurk. 2e Ser. XLVIII, no 2 (The African Species of Oldenlandia), p. 16, footnote (1952). 
transferred to Simira, I will, to begin with, do this with the two species on which the genus was founded. For Sickingia erythroxylon Willd. I therefore propose the new combination Simira erythroxylon (Willd.) Brem. and for Sickingia longifolia Willd. the new combination Simira longifolia (Willd.) Brem. I am practically certain that all the Sickingia species enumerated by ScHumanN, with the exception of S. pisoniiformis (Baill.) K. Sch. which differs i.a. in the very small number of ovules, should be transferred to Simira, but I am not fully certain with regard to all the species that subsequently have been described, and for this reason I would prefer to leave the decision to a future monographer. One of the species enumerated by SchumanN happens to bear the same epithet as AubLeT's species, but as this Sickingia tinctoria (H.B.K.) K. Sch. is conspecific with Sprucea rubescens Bth., the epithet of the latter is available for the new combination. In the introductory paragraph of this paper I stated that Simira tinctoria was until very recently known only by AUBLET's specimens. The specimens that recently have come to light, were obtained from a numbered tree in the former Forest Reserve Kaboerie, Suriname and are preserved in the Utrecht Herbarium. Unfortunately the material consists of sterile twigs only. 